\title{
Climate Adaptive Agricultural Innovation in Nepal: Prospects and Challenges
}

\author{
Dhanej Thapa, Yuba Raj Subedi and Hemant Ojha \\ Additional information is available at the end of the chapter
}

http://dx.doi.org/10.5772/intechopen.72371

\begin{abstract}
It is evident that agriculture of Nepal is the most sensitive sector to climate change, and adaptations are essential for protecting the livelihood of rural poor farmers and ensuring their food security. Farmers are adopting different practices with climate awareness and sometime with spontaneity. In this chapter, we examined whether these climate change adaptation responses are adaptive and innovative and take into consideration existing and projected climate change and variability. Based on the review of adaptation theories and innovation approaches, researchers primarily draw a climate-adaptive agricultural innovation framework. We looked at empirically captured adaptation practices and analyzed their climate adaptive nature based on productivity, resilience, and equity. This study blends both qualitative and quantitative methods - combining case study of ricewheat system with quantitative survey from four different regions of Terai, Nepal. The study shows that while agricultural system demonstrates a number of practices that contribute to adaptation, there are fundamental institutional, technological, and policy challenges that restrict the prospect of agricultural innovation required to adapt to changing climate.
\end{abstract}

Keywords: climatic stresses, agricultural adaptations, rice-wheat system, innovations

\section{Introduction}

\subsection{Agriculture in climate change context}

Agriculture is the most sensitive sector to climate change [1], as it can be affected by change in temperature, radiation, rainfall, soil moisture, and carbon dioxide $\left(\mathrm{CO}_{2}\right)$ with complex relationships [2]. Different climate change impact and sensitivity analysis conducted in global and regional levels have suggested decline in global food production [3-5]. However, climate 
change impact in agriculture is not uniform to all regions [6]. South Asian agriculture suffers more as three-fifth of the cropped area is rainfed; annual success of the monsoon determines well-being of millions of farmers [7].

Nepal, among the South Asia, is highly vulnerable and is ranked as a fourth most climate vulnerable country in the world [8]. Its fragile agro-ecology, flood-prone Terai region, weak infrastructural status, and poor economic condition put country to the vulnerable state [9]. It is estimated that the environmental income contributes to $50 \%$ of national GDP with agriculture, forestry, and fisheries [10]. Agriculture, which is largest contributor to Gross Domestic Product (GDP) of Nepal, is highly climate sensitive since only $53 \%$ of arable lands have year round irrigation facility [11].

Different studies conducted in Nepal suggest that farmers are suffering with climatic stresses of erratic nature of the monsoon rainfall pattern and climate extreme events [12-15]. Monsoon rainfall, which is more than $75 \%$ of total rainfall, determines the overall crop production of Nepal. Some time it has detrimental effects with increased precipitation during the monsoon with floods in lowland of Nepal. It is found to be an increased mean annual precipitation; with a decrease of rainy days with increased number of high-intensity rainfall events. It is recorded in most of the metrological stations of Nepal [16]. This scenario of rainfall intensity indicates more weather-related disasters, such as floods and landslides in future. Some studies show that flood incidence increased in Nepalese context has sharply declined crop production [17], severely affecting the life and livelihoods of the people in the entire Terai (lowland) region of Nepal. Every year, large sections of agricultural land are washed away by floods, and also degrading the land making it unsuitable for cropping. A research conducted by ICIMOD on the impact of climate change on water resources in the Himalayas shows that flooding will likely increase due to longer and more erratic monsoons, more intense rainfall events, and snowmelt, while droughts will increase due to glacier loss and changes in precipitation variability [18].

It is crucial for the Nepalese agriculture to adapt with climate change, since more than $66.5 \%$ of populations are primarily depended on agriculture. However, adapting to changing climate conditions is a huge challenge. This is particularly so for agriculture, which is generally well-adapted to mean or average conditions, but is susceptible to irregular or extreme conditions. More frequent droughts, floods, and deviations from "normal" growing season conditions, long-term changes in mean conditions, such as cumulative heat and timing of frosts, will have negative implications on agriculture $[19,20]$. It is therefore necessary to understand the existing agricultural adaptation practices and critically analyze climate adaptability with existing and projected climate change and variability.

\subsection{Concepts of climate change adaptation}

According to dictionaries, adapt means to make suitable by altering. According to the Third Assessment Report of IPCC of 2001 [17], adaptation has been defined as adjustment in ecological, social, or economic systems in response to actual or expected climatic stimuli and their 
effects or impacts. This term refers to changes in processes, practices, or structures to moderate or offset potential damages or to take advantage of opportunities associated with changes in climate.

In agriculture, adaptation can be differentiated in the agro-biological system and human system. In agro-biological system, adaptation is always reactive, i.e., water stresses to rice shows lower rate of transpiration to minimize water stress; whereas, in human systems, it can also be anticipatory. Based on spontaneity of adaptation, it can be autonomous or planned [21]. Reactive and autonomous responses of human and natural systems do not necessary minimize short-term agricultural losses. The ecological, social, and economic costs of relying on reactive and autonomous adaptation to the cumulative effects of climate change are substantial. Also, short-term strategies taken by farmers and private sectors may have negative affect to long-term environmental damage. Adaptation to non-climatic stresses, however, influences adaptation to climate change, because it may increase the risk on mal-adaptation and thus reduce the resilience of a system to subsequence changes in climatic conditions [22]. So many of these costs can be avoided through planned and anticipatory adaptation. IPCC [19] report suggests that appropriately designed many adaptation strategies could provide multiple benefits in the medium and longer terms.

\subsection{Climate change adaptation in agriculture of Nepal}

In order to strengthen planned adaptation, Nepal has developed different policies and setup institutions. The Climate Change Policy (2011) and National Adaptation Programme of Action (NAPA) are the principal national-level policy and planning documents on climate change. To implement NAPA priorities at the local level, the government initiated of Local Adaptation Plans of Action (LAPAs) which involve the integration of top-down and bottomup approaches to mainstream adaptation into planning from the local to the national level. Guidelines for LAPAs are included in the National Framework on Local Adaptation Plans for Action (Ministry of Environment, 22 November 2011), which provides the framework for the NAPA (and the Climate Change Policy 2011) to meet its mandatory provisions to disburse at least $80 \%$ of the available budget for the implementation of adaptation and climate change activities at the local level.

Ministry of Agriculture and Development (MOAD) has formulated Agriculture Development Strategy (ADS) 2015, which has a key component of biodiversity conservation and climate change adaptation and mitigation by (i) support the Local Adaptation Plan for Action (LAPA), (ii) scale up the interventions on soil conservation and watershed management including measures to promote adoption of sloping Agriculture Land Technology (SALT), and crop management practices (crop rotation, tillage, etc.), (iii) develop with policy decision, implement, and scale up schemes related to payment of environmental services including carbon sequestrations, and (iv) promote use of alternative/renewable energy and energy saving scheme among the local forestry groups. Recently, Ministry of Population and Environment has been in the process of preparing National Adaptation Plan (NAP) building on NAPA. While NAPA 
was immediate and short-term responses, NAP has planned to identify vulnerability and adaptation response for medium- (by 2030) and long-term (by 2050).

However, there seems still gaps and lack of understanding on how climate change impacts and adaptation needs will be identified and monitored in medium- and long-term. Even though many policies and plans have been formulated in favor of agriculture, but poorly executed within current institutional system. It is still a challenge for Nepal to comply its adaptation strategies with the existing and future climate change impacts and its uncertainty. With a wide micro-climatic variations and poorly managed limited hydro-metrological stations, weather-smart agricultural interventions, and crop-yield forecasting have a long way to go. In most cases, farmers are autonomously adapting with perceived climate risk in the local context. Nepal is still facing a challenge to identify and catalyze adaptive innovations, which can make agriculture resilience to the future climate change impact and associated uncertainty.

\subsection{Conceptual framework of study}

No matter what climate change adaptation options are and how they are determined, it should be climate adaptive with existing and future climate change. Accomplishing this task requires analysis of adaptation of farming and food systems from multiple lenses and approaches. Agricultural innovation system research has provided much useful information on the nature and dynamics of agricultural production systems and their responses to climatic and nonclimatic stimuli. It characterizes agriculture as a complex system, within which changes are driven by the joint effects of economic, environmental, political, and social forces [23, 24]. This approach emphasizes the need to move from linear technology transfer model to more complex, process-based, interactive, and systems-oriented view of agricultural change and innovation.

In this chapter, we combine ideas on climate change adaptation with agricultural innovation and conceptualize climate adaptive agricultural innovation to understand and analyze adaptive responses of farmers and the local actors in relation to different stimuli from climate change and other socio-economic drivers. In understanding climate adaptive agriculture innovations, how farmers perceive risks and how they respond is certainly important, but how other actors and institutions mediate and shape even the farmers' perception and capacity is equally, and perhaps more, important in certain situations. Different studies have shown that decisions involving changes in agriculture are made at different levels by different agricultural actors that are interrelated with each other to form new pattern of agricultural system. In agricultural systems, farmers are the key actors, but they are not the autonomous agents. They are connected with traders, extension agents, fellow farmers, seed suppliers, and government regulators. The nature of farmer action is partly what farmer knows and partly what other actors advise or entice. In this research, we aim to explore the nature of such relations in relation to different innovations (Figure 1).

Our presumption is that farmers and agricultural stakeholders have been adopting their practices in relation to climate change and other drivers. But, due to the longer-term changes involved in climate regime, interventions based on local perceptions may not be fully adaptive 


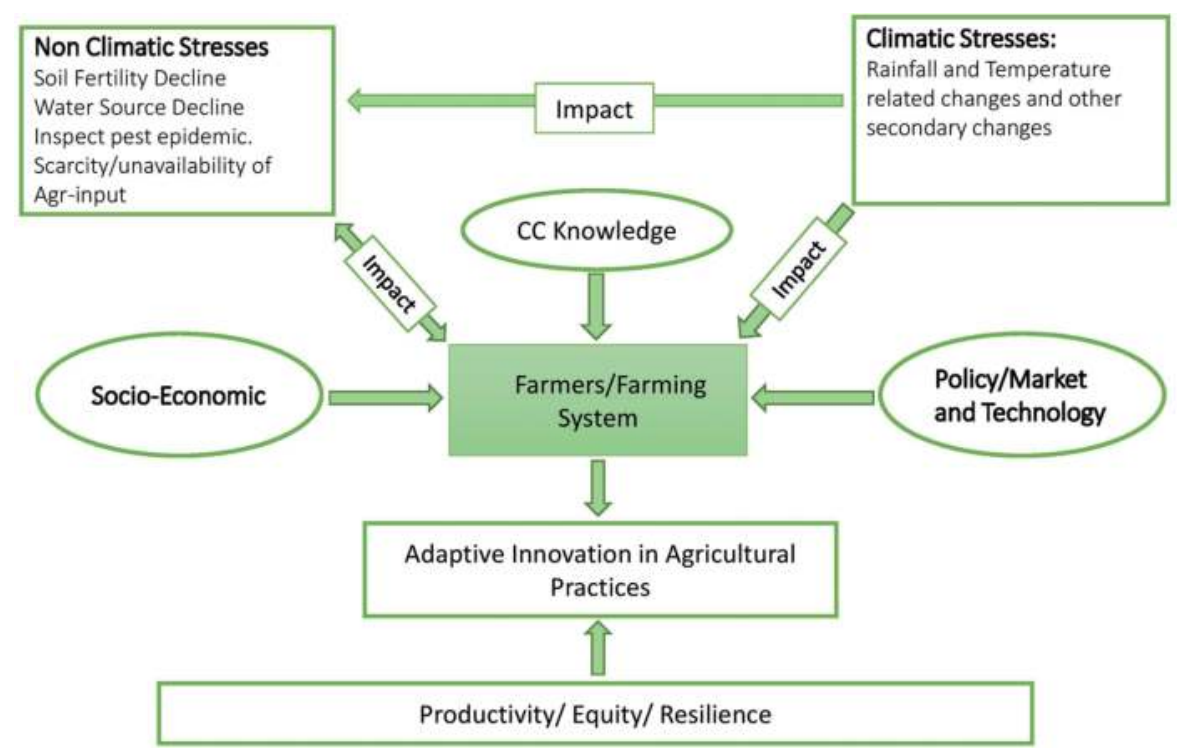

Figure 1. Conceptual framework of study.

to current and future potential risks. Establishing linkages among drivers, climate risks, and adaptation processes with respect to specific risks and opportunities can generate important insights into how climate change adaptation policy approach can be reframed to enable such adaptive practices in agriculture. Climate adaptive innovation practices are being been evaluated through farm productivity, resilience and equity; however farm and farmers' resilience is center of all.

\section{Methodology}

Both qualitative and quantitative inquiry approach has been taken for this study. Qualitative Inquiry approach has been taken to gather human experiences as a subjective experience, in different social context, and in historical time [25]. It is more to uncover knowledge about how farmers think and feel about different climatic stresses and their responses in local circumstances in which they find themselves.

Based on review of adaptation theories and innovation approaches, researchers primarily draw climate adaptive agricultural innovation framework. We look more at how the key actors like farmers, service providers, and regulators perceive, learn, and respond to diverse impacts of climatic change and variability on agriculture. Majorly, primary data are gathered from various studies conducted by the authors, including the one conducted with support from Climate Change Agriculture and Food Security (CCAFS), titled "Climate Adaptive Innovation: A Study of Agricultural Adaptation and Innovations in the Indo-Gangetic Plains, South Asia". 
This study blends both qualitative and quantitative methods-combining a detailed case study of rice-wheat system with quantitative survey from four different CCAFS Block ${ }^{1}$ (CB) of Terai, Nepal.

We purposively selected four districts (Sunsari, Rupandehi, Banke, and Kanchanpur) as our research site. Among five CBs of Nepal, only Sarlahi was not included mainly because of practical feasibility conducting the field work due to security situation at particular time. $\mathrm{CBs}^{2}$ of Nepal are representative sites of Indo-Gangetic Plains in Nepal popularly known as Terai land [26]. The rice-wheat system is a common cropping practice in southern lowland Terai region, the bread basket for entire country. The two crops in the rice-wheat system together contribute more than $72 \%$ of total cereal production of Nepal [27]. Rice-wheat system is largely practiced in low land areas due to abundant fertile alluvial soils.

In order to conduct qualitative studies, Rupandehi district is selected, which is a lowland Terai of west-central Nepal. In the district, we purposively selected Hattibangai village development committee (VDC) for our detailed case study - considering the dynamic responses of agricultural stakeholders in the area. The VDC is located at the bank of Tinau River and is close to a major town in Nepal called Bhairhwa (Siddhartha Municipality). It is accessible by a black-topped road that crosses the village, and all the nine wards of the VDC are also connected to gravel roads. The community is heterogeneous comprising mixed caste groups and indigenous groups and new migrants. There are altogether 1076 households in the VDC spread out in the nine wards. Agriculture is either rainfed or irrigated through deep tube wells. The average land holding is 0.91 ha (Figure 2).

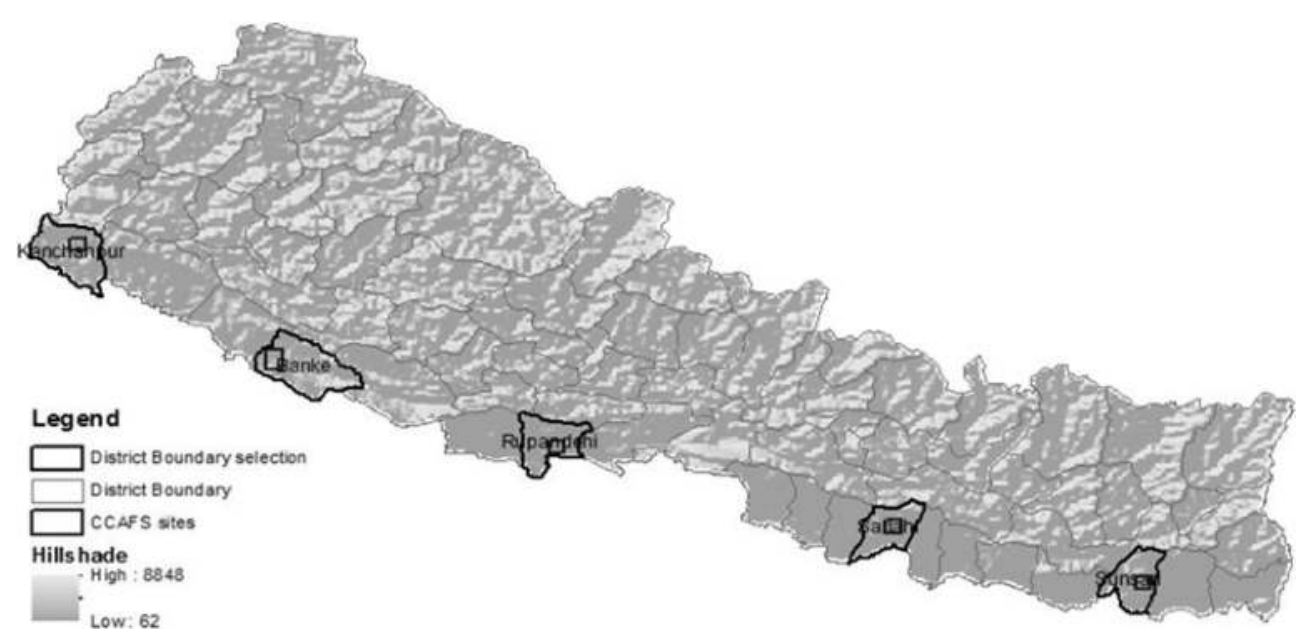

Figure 2. Map of Nepal showing CCAFS blocks.

\footnotetext{
${ }^{1}$ Climate Change Agriculture and Food Security (CCAFS). ${ }^{2}$ CCAFS blocks are $10 \times 10$ sq. m areas, where baseline survey has already been conducted by CGIAR Research Programme on Climate Change Agriculture and Food Security.
} 
Primary data were collected through different tools. Household survey was carried out in all four CCAFS block. Where as key informant interviews (KIIs) at community and district levels and focus group discussions (FGDs) with women and poor farmers, and household focused case-lets were done only in CCAFS block of Rupandehi district. During discussion and survey, climate-related questions were asked in later stage so as to avoid bias answer from participants.

All together 80 households, 20 households from each CB were selected for sampling survey. To make households more representatives in household's survey, three villages of CBs were selected using the map and list of villages from the CCAFS baseline data. Three villages of 200 hhs each located in $1 \mathrm{~km}$ of North-West corner of block, closest to center of block, and within $1 \mathrm{~km}$ of SE corner of block were taken for survey. With help of key informants in village, list of households were categorized into (a) big farmers and (b) small-marginal (landpoor) farmers. Among of them, sample of three big farmers and three small-marginal farmers were randomly selected from two corners of the block, whereas a sample of four big farmers and four small farmers were selected from the center.

\section{Findings and discussion}

\subsection{Agricultural system changes and innovation}

There are continuous changes observed in agriculture of Terai, Nepal. In dominant rice-wheat system, farmers have introduced multiple changes. Most of the respondent farmers were smallholders and were practicing subsistence agriculture followed by selling marketable surplus agri-products. Leasehold or share-cropping was very common to meet the need of sufficient food. Besides, agriculture was not only basis of livelihood; in fact, remittance played significant role in household annual income.

In recent years, farmers have either shifted to different agricultural practices or adopted new crop management practices. Nearly, $60 \%$ of respondent farmers shifted to new agricultural commodities. Vegetable cultivation was a chief source of new income sources to farmers. In most cases, winter-wheat crops were replaced by vegetable crops. About $50 \%$ of the respondent farmers of Banke district and 35\% of the Kanchanpur district added vegetables. However, only $15 \%$ of respondents of Sunsari and $5 \%$ of Rupandehi district added vegetable crops in their farm. Around 5\% of respondent of Kanchanpur district shifted to poultry production. A huge shift in banana farming was also observed in Rupandehi and Sunsari district. More than $15 \%$ respondent farmers of Rupandehi and $10 \%$ of Sunsari switched to banana (Table 1).

Most of them reported that shifting to new crops was more for higher income and for market security of these crops. It was noticed that most of the smallholder farmers had gone to such new changes. Smallholder famers did not prefer to cultivate rice-wheat crops.

One of the smallholder farmers of Rupandehi told us "In wheat production I used to have a return of only NPR 20-25 thousand per 0.75 hectare of land, but in banana farming, it is possible to have a net income of more than NPR. 0.3 million." 


\begin{tabular}{llll}
\hline Block name & Old & New & Percentage of farmers \\
\hline Banke & Rice-wheat & Vegetable & 50 \\
Kanchanpur & Rice-wheat & Vegetable & 35 \\
Rupandehi & Rice-wheat & Vegetable & 5 \\
Sunsari & Rice-wheat & Vegetable & 15 \\
Rupandehi & Rice-wheat & Banana & 15 \\
Sunsari & Rice-wheat & Banana & 10 \\
Kanchanpur & Rice-wheat & Poultry & 5 \\
Rupandehi & Rice-wheat & Pond fish & 5 \\
\hline
\end{tabular}

Field survey 2012.

Table 1. Households changing agricultural component/commodities over the 5 years.

Those farmers continuing similar crops have changed their crop management practices. However, time-related changes (changing time of agronomic management practices) was very less as compared to technological changes of crop management practices. Around $66 \%$ of respondents adopted new technology in land preparation. Farmers started to use tractors for land preparation. After decline of bullocks, use of tractors was common among farmers. However, introduction of tractor is not new in Nepal; a large number of farmers were also using tractors previously. In addition, farmers are also using new machines like rotavators ${ }^{3}$ for land preparation during winter season for wheat crops. This has minimized the multiple tillage practices. Similarly, use of rotavators reduced the problem of water stress problem for low soil moisture by multiple tillage practices. More than $81 \%$ respondent farmers adopted new varieties in similar crops. In Hattibangai area of Rupandehi, more than $80 \%$ of farmers were using Indian hybrid rice (Gorakhnath) and Nepali drought tolerant Radh-4 rice varieties. Around $61 \%$ respondent farmers changed sowing and transplanting technologies. There were also significant changes in post-harvest operations technologies and use of pesticides, whereas shift in irrigation and harvesting technology was done by 66 and $64 \%$ of farmers, respectively.

Most of the respondents changed time of agronomic practices due to use of tractors, rotavator, and zero tillage accessories and combine harvesters. Also, time-related changes are more determined by adoption of new short duration varieties. Currently, time and frequency of multiple land preparations have changed. Majority of the farmers were being fully dependent on these new mechanical tools for land preparation (Table 2).

A research conducted by Thapa [28] used logistic regression model to analyze influencing non-climatic factors to switch new crops. Among the factors, contact with government organizations, climate awareness, subsistence farming were insignificant; whereas, small landholding farmers were 3 times more likely to switch toward new crops. Farmers' motive to switch new crops was largely driven by market profit. Similarly, farmers consulting to agro-vet were 


\begin{tabular}{|c|c|c|c|c|c|c|}
\hline \multirow{2}{*}{$\begin{array}{l}\text { Agriculture management } \\
\text { practices }\end{array}$} & \multirow[t]{2}{*}{ Changes in } & \multicolumn{4}{|c|}{ Block name } & \multirow[t]{2}{*}{ Total } \\
\hline & & Banke & Kanchanpur & Rupandehi & Sunsari & \\
\hline \multirow[t]{2}{*}{ 1. Land/soil preparation } & Time & 25 & 50 & 55 & 25 & 39 \\
\hline & Technology & 40 & 55 & 100 & 70 & 66 \\
\hline \multirow[t]{2}{*}{ 2. New/crops varieties } & Time & 25 & 65 & 65 & 75 & 58 \\
\hline & Technology & 75 & 75 & 100 & 80 & 82 \\
\hline \multirow[t]{2}{*}{ 3. Sowing/transplanting } & Time & 11 & 75 & 35 & 80 & 51 \\
\hline & Technology & 11 & 90 & 70 & 75 & 63 \\
\hline \multirow[t]{2}{*}{ 4. Purchase/use of pesticides } & Time & & 100 & 30 & 50 & 50 \\
\hline & Technology & 44 & 95 & 100 & 70 & 78 \\
\hline \multirow[t]{2}{*}{ 5. Irrigation } & Time & 70 & 100 & 65 & 50 & 71 \\
\hline & Technology & 55 & 95 & 100 & 20 & 68 \\
\hline \multirow[t]{2}{*}{ 6. Harvesting } & Time & 60 & 74 & 100 & 45 & 70 \\
\hline & Technology & 60 & 74 & 100 & 30 & 66 \\
\hline \multirow{2}{*}{$\begin{array}{l}\text { 7. Use/purchase of new } \\
\text { agricultural implements }\end{array}$} & Time & 50 & - & 40 & 30 & 24 \\
\hline & Technology & 50 & 30 & 65 & 60 & 51 \\
\hline \multirow[t]{2}{*}{ 8. Post harvest operations } & Time & 30 & 21 & 46 & 35 & 32 \\
\hline & Technology & 20 & 40 & 90 & 50 & 50 \\
\hline \multirow[t]{2}{*}{ 9. Marketing } & Time & 20 & 5 & - & - & 7 \\
\hline & Technology & 10 & 10 & - & 5 & 7 \\
\hline
\end{tabular}

Field survey 2012.

Table 2. New changes in agriculture management practices (in percentage).

4.8 times more likely to switch toward new crops. Famers consulting agro-vet got exposure on benefit from new crops as well as technical inputs for growing new crops.

Within rice-wheat system, farmers have adopted new practices such as improved varieties of rice and wheat from India as well as some released and registered varieties from Nepal. Improved varieties or rice imported from India and adopted by farmers are, Sarju 52, Sarju49, Sava Mansuli, and Gorakhnath Gold. Similarly, Nepali improved varieties of rice adopted by farmers of Rupandehi are Mansuli, Loktantra, Mithila, Radha-4, and Barkhe-2b [29]. For wheat crops, National Wheat Research Program (NWRP) Rupandehi has introduced different varieties of wheat Bijay, Adhitya, and Brikuti with such characteristics as early maturing, drought resistance, and tolerance to pests and diseases. They are also popular among farmers of Rupandehi district [30].

Similarly, fish farming, which gives a higher return in a shorter period than rice farming, has also been adopted by farmers as a response to the repeated problems of floods washing away the rice crop and of declining yields. As a result of this development, farmers' income 
has increased due to fish farming, but at the cost of a decreasing rice plantation area [29]. Farmers of Rupandehi have gone through series of agricultural experiments in their farms such as cash crops, vegetables, banana, fish, and other management practices [31]. A CCAFS sites in Rupandehi exhibit the highest levels of diversity in production, with over $50 \%$ of surveyed households producing more than eight different products [32]. However, such changes are shaped by different factors. In lowland with clay soils, farmers have shifted to fish pond where as in low sandy loam soils, farmers have shifted to banana crops.

If we see the household priorities and behavior, in terms of flexibility toward adaptive change and belief in investing in new innovations, smallholders' farmers are adopting labor intensive income oriented cash crops. Whereas, large holder famers managed labor scarcity, thereby increased use of new machines. There are other changes and adaptation responses such as (i) increasing attraction toward crop security program, (ii) changing their seeds in $2-3$ years, (iii) crop rotation with legume crops, (iv) increasing trend of groups and co-operatives formation and private agro-vets.

\subsection{Climate change realities and farmers' perceptions}

However, all the changes in agriculture of Terai are not well informed by existing climate change. It seems more autonomous with certain climate stimuli and market. There exist huge gaps in understanding the climate adaptability of these changes and adaptation responses. Local people shared some experiences of the climate conditions, but most of the respondents were not aware about climate change. However, they have felt different climate extreme events and negative impact to agricultural production. Farmers were showing their direct concerns on precipitation rather than temperature-related issues. Rice farmers were worried about uncertain monsoon rainfall. Delayed and uncertain monsoon has left farmers in dilemma specially in raising the nursery bed.

One of the farmers of Gargatti village of Rupandehi remembered. "It used to be delay in monsoon rainfall in the past years but this year it was early rain and we did not have rice seedlings for transplanting. Rainfall was continuous but we were unable to transplant rice". A Chief of District Agriculture Development Office (DADO) added "monsoon came early in last year and very less precipitation was seen in August and September, drastic reduction in mid and late varieties like Sawa Mansuli and Sunaulo Sugandha varieties of rice".

While asking famers about their future risk perception, $49 \%$ farmers said drought as very serious risk in future as well and 55\% farmers feel that somewhat serious.

In case of temperature related changes, only few of them linked to their current agricultural practices. Wheat farmers have felt that wheat-growing season is being delayed. Usually, the farmers used to seed wheat during first week of November. But now, they have shifted to the third week of November. Senior Scientist from National Wheat Research Program (NWRP) told us that generally November 15 is used to be the appropriate time for wheat sowing, but now wheat sown 10 days later gives more yield.

However, famers' perception on climate change and overall ranking taken from weighted mean showed six major climatic stresses perceived by farmers. Rainfall difficult to predict, 
drought, increasing summer temperature, monsoon starts earlier, winter has become cooler, and more rainfall intense rainfall during monsoon were ranked from one to six.

The analysis of 30 years climate data shows that there is evidence of climate change in the study site. Monsoon precipitation anomaly generated from 30 years monthly rainfall data from the nearest meteorological station (Bhairahawa Airport) highlighted the decreasing trend of precipitation in the area. This is linked with the farmers' perceptions on increasing drought condition and increasing summer temperature. Interestingly, drought was more emphasized by local leader farmers and district stakeholders and agro vets. However, there were floods in the years of 1981, 1984, 1989, 1998, and 2006.

However, our survey finding revealed drought as fifth important observation. This might be due to excess use of ground water for irrigation. Farmers were using their boring water for irrigation. Farmers in Hattibangai and Rupandehi areas have also perceived decline of water table. Farmers reported that deep-tube wells/boring sets need to go further depth for harvesting water. According to farmers' perception, water table has declined from 180 to $280 \mathrm{ft}$. A research conducted by Dahal et al. [33] suggested decline of water table in nearby areas. Even some of the Shallow Tube Wells $(7.62 \mathrm{~m})$ were dried during dry season (from April to June) in many cases in the vicinity of the Tinau River. However, drying of Shallow Tube Wells (STW) was linked with excess riverbed extraction of Tinau River. In the same paper, it was clearly argued that decline of water table of deeper STW depths from 28.96 to $36.58 \mathrm{~m}$ were not affected by the extraction in the Tinau River. In the case of Hattibangai and nearby VDCs, Bhairawa Lumbini Groundwater Project constructed number of deep boring sets for irrigation purpose. Excess of ground water harvesting by deep boring sets led to the decline of water table. In case of declining precipitation, water table failed to recharge as per required. So, we can conclude that decline of water table is more linked with decrease of precipitation.

The analysis of 30 years of temperature data shows a slight increase in minimum temperatures while maximum temperatures have remained the same [29]. While taking farmers perceptions, $49 \%$ respondent farmers' perceived decrease of winter temperature and $81 \%$ of farmers accepted negative effects due to chilling winter. However, climate data showed increase of minimum temperature. Few farmers' perceptions were matched with the climate, while others did not. While analyzing the perception of farmers on rainfall, around $42 \%$ of respondents reported that intensity of rainfall was increasing, while precipitation analysis showed a decline of rainfall during the last 10 years. However, if we look at the precipitation of Butwal station, sharp increase in rate of precipitation was observed [28].

Late monsoon and hotter winter were insignificant to explain influencing climatic factors to switch crops. Farmers experiencing drought were 5.5 times more likely to switch new crops, as compared to those who did not experience drought as a problem. Similarly, farmers experiencing early winter more severe were 8 times more likely to switch new crops [28].

Since the study was conducted in rainfed area, farmers significantly used tube wells for irrigation. However, it was more costly and farmers were demotivated for frequent use of tube wells. Similar with our research finding, another research of Gauchan and Gumma [34] showed that drought incidence has increased in Nepalese context. This study analyzed production and productivity by analyzing satellite images taken spatially and temporally on 
rice crops and drought years. This can be predicted that with increasing climate change, such situation can be further devastating. Amgain et al. [35] in their simulation study in Indian context indicated that increments in both maximum and minimum temperatures by $4^{\circ} \mathrm{C}$ decreases rice yield by $34 \%$ and wheat yield by $4 \%$ as compared to base scenario with current weather data. However, in Nepalese context, hot summer was significant, but farmers were 0.144 times less likely to switch crops as compared to that respondent who did not experience hot summer. These research findings suggest that farmers are changing cropping pattern as a short-term strategic actions to cope with problem of water.

It is obvious that farmers have experienced climate risk. Their perceptions on climate change and consequences were sometime matched with climate data analysis, whereas contradictory in many cases. There are strong gaps existing between the predicted level of climate change and the actual adaptive actions among both the farmers and other locally based agriculture stakeholders, suggesting the deficit of processes and institutions to facilitate adaptive innovations. By and large, climate science data still remains within the research institutions, not readily accessible to agricultural actors.

\subsection{Adaptive innovation support system}

Adaptive activity does not occur in institutional vacuum [36]; range of institutions from household to community to government systems affect choices of individual farmers. Several institutional changes are noticeable.

Extension policies supported the formation of cooperative groups, which enable to continue banana farming, rice-wheat crop intensification, and farm mechanization. Promoting private sector policies encouraged to establish agro-vets in local level, providing seeds/pesticides and technical information to vegetables growers. Generally, farmers contact to government organizations for new agricultural implements, whereas co-operatives and private agro vets for seeds and pesticides, respectively. Farmers are usually depending on local institutions like co-operative, VDC level government agricultural service centers. However, climate information was not shared by such institutions. Farmers have limited access to climate related information. Only 23\% farmers were getting weather forecasts. Among of them, $36.3 \%$ of them were receiving from radio. $31.5 \%$ from community meetings, $25 \%$ farmers from "extension workers" and 14\% from "neighbors." Whereas, the use of "mobile phone," "email/internet," and "newspaper" were relatively very low.

Farmers usually do not visit meso-level institutions located at district for climate agricultural information. Farmers' perceptions and responses toward climate change are more autonomous actions and lesser based on scientific knowledge of climate change gained from extension services. Still there are key barriers like poor access to mass media, and poor information flow on climate change. Farmers think for need of more community meetings and workshop facilitated by meso-level extension agencies rather than mobile SMS and other mass media. Agricultural extension system, which is largely within government, is also slow to adapt and communicate climate science to farmers, as there is still limited institutional priority accorded in processing and communicating the scientific knowledge. 
Market is becoming an important driver to agricultural change. It is not just the market of agricultural inputs or outputs but also the opportunity costs or the relative value of substitutes for producing agricultural commodities. With the shut down of the sugar factory in Rupandehi district, it was a poor demand for sugarcane and so farmers switched to banana crops. Market has become a handy provider of inputs and even technical advices to farmers. Seed store/agro-vets are examples local agribusinesses, which largely influence decisions of farmers. Larger equipment such as tractors/other farm mechanization tools are also available in the small and medium size towns. These also make it possible for the small farmers to access the services of relatively costly equipment on per hour basis without a need to own. Besides, sometime farmers suffered with numerous problems regarding different issues of crop failure due to seed sterility, low market price, and unavailability of seeds and fertilizers. Adaptive innovations are not just steered through incentives or disincentives offered by policy or something that occur in response to the market based incentives.

Technologies are being introduced in farms with multiple interactions of market, extension and farmers network. Currently, Terai of Nepal has different levels of technological sophistication in agriculture. Government policies and market forces both promoted mechanization. Subsidies exist to enable farmers to have access to technologies. But, the production focus is not clearly articulated with longer-term adaptation to climate change. Some climatefriendly technologies introduced earlier are lesser practiced by farmers such as zero tillage, integrated pest management (IPM), and sustainable soil management (SSM). There is a lack of fundamental rethinking on the need to link technology with sustainability and resilience. In Rupandehi, zero tillage was introduced to farmers to sow wheat as soon as rice is harvested, and the crop matures before hot winds of spring shrivel undeveloped grains. However, farmers are more attracted toward rotavator, which have many negative implications to soil properties and moisture conservation.

Civic engagement compliments an important part $[37,38]$ in climate adaptive innovation. This includes farmer-to farmer co-operation, formation of associations for advancing the interests and concerns, and even lobbying with political leaders on policy issues affecting agriculture. There seems increasing number of farmers' organizations/network (formal/informal), especially groups of farmers. Hattbangai, Rupandehi has diverse groups - famer groups, women farmer groups, saving credit groups, few groups form by DDC/VDC and I/NGOs. They have introduced different agriculture practices and farmers were overwhelmingly positive to the opportunity they received in participating in various activities. More than $76 \%$ of respondent farmers found it useful. As the Nepal's political environment is becoming democratic, farmers have enjoyed more opportunities in organizing themselves. However, there was also a challenge to active civic engagement due to factional divisions among political parties.

Agriculture policy approach continues to be top-down and linear [39] while there is an increasing need for "a comprehensive and dynamic policy approach, covering a range of scales and issues" [40] in the context of climate change. The formulation of NAP-Agriculture and ADS 2015, which aimed to direct the climate change adaptation in agriculture, are more or less failed to consider ground realities and complexities of adaptation challenges in farm level. To enhance the adaptability of agriculture, short-term and farm-level adaptation actions 
of farmers should be made part of the efforts to secure long-term resilience of the entire agroecological systems in the localities. However, regulatory responses have remained mixed, but largely ignorant of the current and future effects of climate change on agriculture. In Rupandehi, there was a number of ground water projects, which are currently not functioning with decline of ground water table. There is continuous deepening of Tinau River, affecting irrigation system in long run.

\subsection{Outcome of agricultural changes and innovation}

Adaptive Innovation and equity: Current status of adaptive innovation practices show a number of challenges related to distributional outcomes (equity). In fundamental sense, adaptability of agricultural systems also depends on its ability to deliver equity and fairness. Agricultural changes in different farm practices were not always gender friendly. While assessing status of women's workload changed over the past 5 years, 59\% of respondent farmers said that workload to women during agricultural field preparation has been decreased. However, in sowing crops, $51 \%$ of respondent farmers said that workload has been increased. With use of tractors, combine harvester, rotavators, and irrigation related used of boring sets supported the traditionally defined work of men. Whereas women-involved work such as intercultural operations and sowing of crops were less supported by current mechanization. In fact, in some cases, women suffered more. For example, women of those involved in banana farming invested their extra time and effort for fertilizer and pesticide applications. While on marketing, processing, and storage, we had mixed perceptions on increased, decreased, and no difference. However, slightly more percentage of farmers were saying that workload had decreased. Basically, decisions on these changes are done by male members who may lead to less adoption of women friendly technologies in sowing, transplanting, and post-harvest operations. More than $75 \%$ farmers told that farming decision was taken by male members (Table 3).

\begin{tabular}{llll}
\hline Activities & Decreased & Increased & No difference \\
\hline 1. Getting agri-inputs & 26 & 18 & 36 \\
2. Agricultural field preparation & 39 & 17 & 24 \\
3. Sowing & 10 & 41 & 29 \\
4. Transplanting & 8 & 48 & 24 \\
5. Inter-cultural operation & 10 & 53 & 17 \\
6. Harvesting & 25 & 41 & 14 \\
7. Processing & 30 & 27 & 23 \\
8. Storage & 34 & 27 & 19 \\
9. Marketing & 31 & 14 & 35 \\
\hline
\end{tabular}

Field survey 2012.

Table 3. Status of women's workload change over the past 5 years (in number). 
A number of observations can be made with regard to the equity aspects. Most of the agricultural technology has favored large landholders, male members, and there is limited research attention to explore and develop pro-poor technology. In some instances, NGO support has allowed landless to have access to land and technology. But, there still remains a question on institutional sustainability, as there are no links with established and accountable system of local and national governments. Much of the technological innovations have not addressed the workload of women. Current farm mechanization failed to reduce burden of female farm worker.

Adaptive innovation and productivity: Farming systems are organized around small and fragmented land holding. In such situations, an adaptive action of farmers takes place in small pieces of land and shaped by motive of production maximization. There is little awareness among the meso-level players of agricultural systems on how adaptation and production innovations could and should be combined together. The question then is how short adaptation actions of farmers become part of long-term efficient production, such that short-term adaptive actions do not hamper the ability of the system to adapt to more intense and large scales shocks that are likely in the long run [40]. Some adapt practices such as crop rotation in rice-wheat crops with legumes and crop diversifications. Similarly, bio-intensification was done by $10 \%$ farmers with less priority. Only $23 \%$ of farmers carried out any resource conservation practices in farm, while none of the famers have conducted organic farming as a planned and systemic manner. Fallowing practice has also left by farmers. Only $16 \%$ farmers left fallow for scientific practice.

Current service delivery system is still dominated by state agencies and there is a lack of mechanisms to ensure other non-state institutions to be responsive to the needs of the farmers. For instance, Nepal's Agri-Input Corporation (AIC) had problems with farmers in regular supply of seeds and fertilizers. Famers often compelled to adopt other high-yielding varieties available in market; which are poorly tested local farm context. Famers are overwhelmingly using single crop varieties with aim to increased higher production lead to risk of crop failure. It requires going beyond "intensification" of agriculture, to link options for sustainability and resilience more seriously. Farmers' ability to engage in climate adaptive innovative practice is substantially shaped and mediated by the stakeholders operating at local and meso-levels. The capacity of household to cope with climate risks depends to some degree on the enabling environment of the community, and the adaptive capacity of the community is reflective of the resources and processes of the region [41]. But, everywhere such meso-level institutions demonstrate much less adaptive response than the farmers.

Adaptive innovation and resilience: Different farm level changes in agriculture are outcome of their transformative learning; triggered disorienting dilemmas to farmers. Social learning in agricultural and natural resource management has remained a key aspect to keep the system resilient. Learning can take place as anticipatory [42] or can occur as transformative change [43] following some crisis. In Rupandehi, a severe hailstone in 2000 damaged one variety (Bhrikuti) of wheat, compared to others (NL 297 and UP-343). Famers are still continuing NL 297 variety, which is discouraged by DADO. Farmer shifted to banana from sugarcane after sudden shut down of sugar factory lead to extra burden to female farmers. Similarly, 
farmers started to sow more than two to three varieties of rice after they suffered with a heavy insect infestation in one variety, whereas less in others. However, such transformative learning and knowledge are remained within small farm level.

In some cases, especially when farmers have access to services and information, farmers have resorted to adaptive and innovative practices - such as changing cropping patterns, technological changes. But again, such innovations lack backing by adaptation thinking informed by an analysis of current and future effects of climate change and variability. Farmers' perception toward climate is not part of their systemic analysis of long-term changes in climate. Farmers are aware of noticeable variation in weather patterns. Farmers linked their problems with hot summer days, erratic nature of monsoon rainfall and drought. However, there exist strong gaps between perceptions of climate change and the adaptive actions among both the farmers and local stakeholders, suggesting the deficit of processes and institutions to translate information into adaptive actions.

Adaptation planning and policy systems have followed traditional sectoral, administrative paths, and at times contributed to maladaptation. The nature of risk varies tremendously across sites and so are the capacities and resources of the actors. The case of water decline is more noteworthy from this point of view - as farmers are all set to maximize individual farm production, while there are little public concerns over the declining water quality and groundwater stock.

\section{Conclusion}

This study confirms that farmers are the active agent of change in agriculture. They experiment, introduce, and experiment different farm level changes with a motive to enhance their farm production, productivity, and sustaining their agrarian livelihood. Farmers have identified different adaptive and innovative responses. However, there is still a lack of framework to understand and catalyze adaptive responses in such a way that it is informed by longterm trends in climate change. There are fundamental institutional, technological, and policy challenges that restrict the prospect of agricultural innovation required to adapt to changing climate. Most of actors have considered private risks in the short run and predominance of market logic. This lacks attention to adaptive aspects - still focusing on productivity aspects, i.e., monoculture of few crops, high yield varieties (HYVs) face major risks, such as over harvesting of natural capital, e.g., ground water.

Farmers' perception toward climate is not part of their systemic analysis of long-term changes in climate. There exist strong gaps between perceptions of climate change and the adaptive actions among both the farmers and local stakeholders, suggesting the deficit of processes and institutions to translate information into adaptive actions. By and large, climate science data still remains within the research institutions, not readily accessible to agricultural actors. Agricultural extension system, which is largely within the government, is also slow to adapt and communicate climate science to farmers, as there is still limited institutional priority accorded in processing and communicating the scientific knowledge. In order to flow of climate information and alertness about climate change are essential. It is necessary to cautiously design effective 
climate information flow system to reached larger numbers farmers. For an agricultural innovation to be climate adaptive, it has to be informed by the expected change in the climate.

Farmers have responded to climatic and socio-economic drivers to agriculture, which involve a wide range of social, technological, political, environmental adjustments, often in association with a wide range of agricultural stakeholders in the region. But, these changes have not been internalized adequately by the institutions and policy systems. In overall, we can conclude that current agricultural system demonstrates a number of practices that contribute to adaptation, but it should be well informed by climate information and facilitated by institution and policy system that enables agricultural innovation climate adaptive to changing climate.

\section{Acknowledgements}

This chapter is based on research on "Climate Adaptive Innovation: A Study of Agricultural Adaptation and Innovations in the Indo-Gangetic Plains, South Asia". This research was conducted by Southasia Institute of Advanced Studies (SIAS) of Nepal with local partner organization Centre for Research on Innovation and Science Policy (CRISP) India and Flood Hazard Research Centre, Bangladesh.

We would like to thank CGIAR Research Program on Climate Change, Agriculture and Food Security (CCAFS) for the funding support. During our research work, we were supported by different public and private institutions working in agricultural sectors. We are thankful to all of these institutions for providing valuable suggestions and information. We also express our deepest gratitude to all the farmers for their active participation and their effective support during our field work.

\section{Author details}

Dhanej Thapa ${ }^{1 *}$, Yuba Raj Subedi ${ }^{2}$ and Hemant Ojha ${ }^{3,4}$

*Address all correspondence to: dhanejthapa@hotmail.com

1 Nepal Development Research Institute (NDRI), Kathmandu, Nepal

2 ForestAction Nepal, Kathmandu, Nepal

3 University of New South Wales (UNSW), Sydney, Australia

4 Southasia Institute of Advance Studies, Kathmandu, Nepal

\section{References}

[1] Agrawal A. The role of local institutions in adaptation to climate change. International Forestry Research and Institutions Program (IFRI) Working Paper. 2008 
[2] IPCC. Climate Change 2007: Synthesis Report. Contribution of Working Groups I, II, and III to the Fourth Assessment Report of the Intergovernmental Panel on Climate Change. In: Pacharuri RK, Reisinger A, editors. Intergovernmental Panel on Climate Change, Geneva, Switzerland; 2007.p. 104

[3] Rosenzweig C, Parry ML. Potential impact of climate change on world food supply. Nature. 1994;367:133-138

[4] Grace PR, Jain MC, Harrington L, Robertson GP. Long term sustainability of the tropical and subtropical rice-wheat system: An environmental perspective. In: Improving the Productivity and Sustainability of Rice-Wheat Systems: Issues and Impacts. ASA Special Publication 65. USA: ASSA-CSSA-SSSA; 2003

[5] Parry ML, Rosenzweig C, Iglesias A, Livermore M, Fischer G. Effects of climate change on global food production under SRES emissions and socio-economic scenarios. Global Environmental Change. 2004;14:53-67

[6] Warren R. Understanding the regional impacts of climate change. Research Report Prepared for the Stern Review. Norwich: Tyndall Centre Working Paper 90; 2006

[7] Kelkar U, Bhadwal S. South Asian regional study on climate change impacts and adaptation: Implications for human development. Human Development Report 2007/2008. UNDP; 2008

[8] Maplecroft. 2010. Available from: http://maplecroft.com [Accessed: 2013-01-12]

[9] Ministry of Environment (MOE). National Adaptation Program of Actions to Climate Change, Nepal. Kathmandu, Nepal: MOE, 2010

[10] World Bank. Nepal Country Environmental Analysis: Strengthening Institutions and Management Systems of Enhanced Environment Governance; The World Bank, Washington DC, USA; 2008

[11] CBS. Agricultural Census Survey, Nepal. Kathmandu, Nepal: Central Bureau of Statistics; 2011

[12] Shrestha AB, Wake CP, Mayewski PA, Dibb JE. Maximum temperature trends in the Himalaya and its vicinity: An analysis based on temperature records from Nepal for the period 1971-94. Journal of Climate. 1999;12:2775-2787

[13] Regmi HR. Effect of unusual weather on cereal crops production and household food security. The Journal of Agriculture and Environment. 2007;8:20-29

[14] Practical Action. Temporal and Spatial Variability of Climate Change over Nepal. Practical Action Nepal: Practical Action Nepal Office; 2009

[15] NCVST. Vulnerability through the Eyes of Vulnerable: Climate Change Induced Uncertainties and Nepal's Development Predicaments. Kathmandu: Institute for Social and Environmental Transition-Nepal (ISET-N, Kathmandu) and Institute for Social and Environmental Transition (ISET, Boulder, Colorado) for Nepal Climate Vulnerability Study Team (NCVST); 2009 
[16] Asian Development Bank (ADB). Climate Change Assessment, Document Stage Draft for Review by Development Partners. Kathmandu, Nepal: ADB; 2009

[17] IDS. Economic Impact Assessment of Climate Change in Key Sectors in Nepal. IDSNepal: Kathmandu, Nepal; 2014

[18] ICIMOD. The Himalayan Climate and Water Atlas: Impact of Climate Change on Water Resources in Five of Asia's Major River Basins. Kathmandu, Nepal; December 2015

[19] Intergovernmental Panel on Climate Change (IPCC). Impacts, Adaptation and Vulnerability. Contribution of Working Group II to the Fourth Assessment Report of the Intergovernmental Panel on Climate Change; 2001

[20] Smit B, Skinner MW. Adaptation options in agriculture to climate change: A typology. Mitigation and Adaptation Strategies for Global Change. 2002;7:85-114

[21] Smit B, Burton I, Klein JT, Wandel J. An anatomy to adaptation to climate change and variability. Climatic Change. 2000;45(1):223-251

[22] Adger WN, Arnell NW, Tompkins EL, Successful adaptation to climate change across scales. Global Environmental Change. 2005;15(2):77-86. ISSN: 0959-3780. DOI: https:// doi.org/10.1016/j.gloenvcha.2004.12.005

[23] Spielman DJ, Ekboir J, Davis K. The art and science of innovation systems inquiry: Applications to sub-Saharan African agriculture. Technology in Society. 2009;31(4):399-405

[24] Hall A, Clark N. What do complex adaptive systems look like and what are the implications for innovation policy? Journal of International Development. 2010;22:308-324

[25] Creswell JW. Research Design: Qualitative, Quantitative, and Mixed Methods Approach. London: Sage Publications; 2003

[26] Forch W, Kristjanson P, Thornton P, Kiplimo J. Initial sites in the CCAFS regions: Eastern Africa, West Africa and Indo-Gangetic Plains. In: CGIAR Research Program. Climate Change, Agriculture and Food Security; Copenhagen, Denmark 2011. pp.1-71

[27] Ministry of Agriculture and Development (MOAD). Statistical Information on Nepalese Agriculture. Kathmandu, Nepal: MOAD; 2015

[28] Thapa D. Climate risk and changing cropping pattern in rice-wheat system of Hattibangai VDC of Rupandehi District [MSc thesis]. Submitted to. Kathmandu, Nepal: School of Arts, Kathmandu University; 2012

[29] Manandhar S, Vogt DS, Perret SR, Kazama F. Adapting cropping systems to climate change in Nepal: A cross-regional study of farmers' perception and practices. Regional Environmental Change. 2011;11:335-348

[30] NWRP. Annual Progress Report. Bhairawa, Rupandehi, Nepal: National Wheat Research Program; 2011

[31] DADO. Annual Progress Report. Rupandehi, Nepal: District Agriculture Development Office; 2012 
[32] Kristjanson P, Garlick C, Ochieng S, Förch W, Thornton PK. Global summary of baseline household survey results. In: CGIAR Research Program on Climate Change, Agriculture and Food Security (CCAFS). Copenhagen, Denmark; 2011

[33] Dahal KR, Poudyal CP, Adhikari P, Sharma S, Ghimre J. Effects of riverbed extraction on ground water resources in the vicinity of Tinau river, Rupandehi. Nepal Journal of Science and Technology. 2012;13(2):133-140

[34] Gauchan D, and Gumma MK. Effect of drought incidence on rice area, production and productivity in Nepal. Estimation of temporal data using remote sensing and socioeconomic methods. A paper presented in IWMI National Conference on Water, Food Security and Climate Change, Nov 23-24, 2011; Kathmandu; 2009

[35] Amgain LP, Devkota NR, Timsina J, Singh B. Effect of climate change and $\mathrm{CO}_{2}$ concentration on growth and yield of rice and wheat in Punjab: Simulations using CSMCERES-rice and CSM-CERES-wheat models. Journal of Institute of Agriculture and Animal Science. 2006;27:103-110

[36] Aggarwal PK. Global climate change and Indian agriculture: Impacts, adaptation and mitigation. Indian Journal of Agricultural Sciences. 2008;78:911-919

[37] Adger WN. Social capital, collective action and adaptation to climate change. Economic Geography. 2003;79:387, 2003-2404

[38] Deniere A, Luong HV, editors. The Dynamics of Social Capital and Civic Engagement in Asia. London and New York: Recherche; 2012

[39] Ministry of Agriculture and Development (MOAD). Agriculture Development Strategy. Singhdurbar, Kathmandu, Nepal: MOAD; 2015

[40] Howden SM, Soussana JF, Tubiello FN, Chhetri N, Dunlop M, Meinke H. Adapting agriculture to climate change. Proceedings of the National Academy of Sciences of the United States of America. 2007;104:19691-19696

[41] Smit B, Wandel J. Adaptation, adaptive capacity and vulnerability. Global Environmental Change. 2006;16(3):282-292

[42] Tschakert P, Dietrich KA. Anticipatory learning for climate change adaptation and resilience. Ecology and Society. 2010;15(11). (online) http://www.ecologyandsociety.org/vol15/ iss2/art11/

[43] Mezirow J. Transformative Dimensions of Adult Learning. San Francisco, California: Jossey-Bass; 1991 